\title{
CONFRONTATION OF Trichoderma asperellum VSL80 AGAINST Aspergillus niger VIA THE EFFECT OF ENZYMATIC PRODUCTION
}

\section{CONFRONTACIÓN DE Trichoderma asperellum VSL80 CONTRA Aspergillus niger A TRAVÉS DEL EFECTO DE LA PRODUCCIÓN ENZIMÁTICA}

\author{
Teresa Romero-Cortes ${ }^{1}$, Pablo A. López-Pérez ${ }^{1}$, Víctor H. Pérez España ${ }^{1}$, Ariadna K. Medina- \\ Toledo $^{1}$, José E. Aparicio-Burgos ${ }^{1}$, and Jaime A. Cuervo-Parra ${ }^{1 *}$ \\ ${ }^{1}$ Universidad Autónoma del Estado de Hidalgo, Escuela Superior de Apan, Carretera Apan- \\ Calpulalpan, Km 8, Chimalpa Tlalayote s/n, Colonia Chimalpa, Apan, Hidalgo. México. C.P. 43900 \\ * Corresponding author. E-mail: jalioscha@gmail.com
}

\section{RESUMEN}

El género Aspergillus ha sido aislado a nivel mundial de plantaciones de cacao, sin embargo, no hay suficiente información sobre su implicación en la aparición de enfermedades. Las cepas de Aspergillus niger se caracterizaron morfológica y molecularmente. Las secuencias de $A$. niger se depositaron en las bases de datos del GenBank. También se evaluó el efecto antagónico de Trichoderma asperellum VSL80 frente a las cepas de $A$. niger, obteniéndose un índice de biocontrol (BCI) de entre 15,36 y $88,71 \%$. Se observó por microscopia electrónica de barrido que las hifas de Trichoderma crecieron en paralelo con las hifas de $A$. niger y en algunos casos se encontraron unidas con las hifas del hongo patógeno impidiendo su desarrollo. Por otro lado, la actividad enzimática máxima de xilanasas producida por $A$. niger en cultivo sumergido fue de $1,128 \mathrm{U} \mathrm{mL}^{-1}$ a las $96 \mathrm{~h}$. La caracterización morfológica y molecular de las cepas de $A$. niger confirmó su presencia en México. Además, la información obtenida del BCI puede ser importante para el desarrollo de estrategias para la prevención y control de este hongo. La actividad enzimática de $A$. niger durante el micoparasitismo por T. asperellum podría explicar el bajo BCI observado en algunas cepas de $A$. niger confrontadas con T. asperellum. Finalmente, la producción de enzimas xilanolíticas por $A$. niger indicó que este hongo podría usarse en la industria para obtener xilanasas.

Palabras clave: Biocontrol, micoparasitismo, Theobroma cacao, xilanasas.

\section{ABSTRACT}

The genus Aspergillus has been isolated from cocoa plantations worldwide. However, there is not enough information about its role in the occurrence of diseases. Aspergillus niger strains were characterized by morphological and molecular techniques. The sequences of $A$. niger were deposited in the GenBank databases. In addition, the antagonistic effect of Trichoderma asperellum VSL80 against $A$. niger strains was evaluated, obtaining a biocontrol index (BCI) between 15.36 and $88.71 \%$. Scanning electron microscopy showed that the Trichoderma hyphae grew in parallel with the hyphae of $A$. niger and, in some cases, they were found together with the hyphae of the pathogenic fungus preventing their development. On the other hand, the maximum enzymatic activity of xylanases produced by $A$. niger in submerged culture was $1.128 \mathrm{U} \mathrm{mL}^{-1}$ at $96 \mathrm{~h}$. The morphological and molecular 
characterization of $A$. niger strains confirms its presence in Mexico. In addition, information obtained of the BCI may be important for the development of strategies for the prevention and control of this fungus. The enzymatic activity of $A$. niger during mycoparasitism by $T$. asperellum could explain the low BCI observed in some $A$. niger strains confronted with T. asperellum. Finally, the xylanolytic enzyme production by $A$. niger indicated that this fungus could be used in the industry to obtain xylanases.

Key words: Biocontrol, mycoparasitism, Theobroma cacao, xylanases.

\section{INTRODUCTION}

Cocoa (Theobroma cacao L.) is a crop with great commercial value worldwide due to the large number of commercial applications cocoa beans have. Unfortunately, diseases caused by fungal pathogens decrease crop yield. In this sense, Aspergillus fungi are considered to be responsible for food spoilage due to mycotoxin production (Soares et al., 2013), and they can also lead to infectious diseases such as pulmonary invasive aspergillosis (Thompson and Patterson, 2008). This fungus is able to contaminate several foodstuffs, particularly cocoa (Mounjouenpou et al., 2012). In Mexico, few studies have focused on the identification of these cocoa fungi (Cuervo-Parra et al., 2011). The morphological and molecular identification of Aspergillus niger strains associated with cocoa crop is important for the development of strategies for their prevention and control.

Filamentous fungi secrete a number of enzymes that are capable of degrading cell wall components of plants (Vásquez, 2013). Cellulases have shown their potential application in textile bioclarification (Kuhad et al., 2011) and in the energy industry (Martínez-Anaya et al., 2008). The growing demand for these enzymes has promoted research, study and use of different lignocellulosic microorganisms. In this sense, filamentous fungi are the main source of hydrolases, including cellulase and xylanase, due to their easy handling and reduced costs (Izarra et al., 2010). Aspergillus versicolor and A. niger are the most widely used species in the production of industrial enzymes, mainly for their high levels of protein secretion, production of extracellular enzymes, easy retrieval and status generally recognized as safe (Gautam et al., 2011).

Therefore, the aims of this study were: (i) characterize morphologically and molecularly eleven strains of $A$. niger; (ii) test the antagonistic effect of $T$. asperellum VSL80 strain against $A$. niger strains; and (iii) determine the capacity for xylanase production by $A$. niger strains through solid medium and submerged fermentation culture production.

\section{MATERIALS AND METHODS}

\section{Fungal strains}

The Aspergillus strains used in this study were isolated from diseased tissue of cocoa fruits from commercial plantations located in the municipality of Huimanguillo, Tabasco State, Mexico. Strains were identified as HT-ITV18, HT-ITV21， HT-ITV24， HT-ITV28, HT-ITV39, HT-ITV42, HT-ITV47, HT-ITV49, HT-ITV51, HT-ITV52 and HT-ITV53. Trichoderma asperellum VSL80 antagonistic strain was obtained from the culture collection of the Genetic Laboratory of the Technological Institute of Veracruz, Mexico.

\section{Morphological analysis}

Morphological descriptions were based on comparisons with other strains of $A$. niger (Silva et al., 2011; Mounjouenpou et al., 2012; Vega et al., 2012). Pure culture strains were incubated in Potato Dextrose Agar (PDA) medium for 7 days and $25^{\circ} \mathrm{C}$. Scanning electron microscope (SEM) pictures (JEOL, Model IT300, Boston, United States of America) was taken at Superior School of Apan-Universidad Autonoma del Estado de Hidalgo, Mexico.

\section{Molecular characterization and phylogenetic analysis}

DNA extraction from A. niger were performed as described by Cuervo-Parra et al. (2014). A region of nuclear DNA of each strain (containing the ITS I/5.8s/ITS II sequence) was amplified by PCR using the primers ITS1 and ITS4 (Kendall and Rygiewicz, 2005). PCR amplifications were performed in a total volume of $50 \mu \mathrm{l}$ reaction, which contained: $10 \mu \mathrm{L}$ of $5 x$ Colorless buffer, $200 \mu \mathrm{M}$ dNTPSs, $0.2 \mu \mathrm{M}$ of each primer, 2.5 units of Taq DNA polymerase, and 10-50 ng of template DNA. PCR reactions were placed in a thermal cycler (Techne PRIME3 Model, Series No. 31309, Staffordshire, United Kingdom) under the following parameters: initial denaturation at $95^{\circ} \mathrm{C} 5 \mathrm{~min}^{-1}$, followed by 30 cycles of denaturation $\left(95^{\circ} \mathrm{C} 1 \mathrm{~min}^{-1}\right)$, annealing $\left(57^{\circ} \mathrm{C} 1\right.$ $\left.\min ^{-1}\right)$ and extension $\left(72^{\circ} \mathrm{C} 1 \mathrm{~min}^{-1}\right)$, and a final extension period at $72^{\circ} \mathrm{C} 5 \mathrm{~min}^{-1}$. The resulting products were purified with the Geneclean ${ }^{\circledR}$ II kit 
(Bio101 Inc., California, United States of America) according to the manufacturer's protocol. DNA sequences from each strain were assembled using the Chromas 1.45 software (School of Health Science, Griffith University, Gold Coast Campus, Southport, Queensland, Australia). Sequences were submitted to a similarity search against sequences entries from the National Center for Biotechnology Information (NCBI) GenBank databases with the BLAST program (Tamura et al., 2013). Phylogenetic analysis of the aligned sequences was done by Neighbor-Joining (NJ) tree generated using Kimura's two-parameter model and supported by bootstrap method using 1000 random replicates with the MEGA v 6.0 software package (Tamura et al., 2013).

\section{Confrontation experiments}

The interactions between $A$. niger and $T$. asperellum VSL80 strains were evaluated by using the technique described by Szekeres et al. (2006). In Petri dishes with PDA medium, three-day-old Trichoderma mycelia discs of 5 $\mathrm{mm}$ in diameter were put at equidistant points and $A$. niger pathogen was left to confront. Petri dishes were incubated at $25^{\circ} \mathrm{C}$ in darkness. Antagonist activities were recorded after a week of incubation and digital images were taken at a distance of $18 \mathrm{~cm}$ with a camera (Cybershot DSC-P72, San Diego, California, United States of America). The percentage growth inhibition of the phytopathogenic fungus $A$. niger was calculated using the biocontrol index $(\mathrm{BCI})$ according to the formula: $B C I=[A / B] \times 100$ (Szekeres et al., 2006), where letter A represents the area occupied by the colony of $T$. asperellum, and letter $B$ represents the total area occupied by the colonies of $T$. asperellum VSL80 and A. niger. BCI was calculated using the software ImageJ (http://rsbweb.nih. gov/). Observations of the interaction region between Trichoderma and A. niger were made by SEM pictures according to Cuervo-Parra et al. (2014). Cuts were mounted on a pedestal with graphite conductive paint and coated with gold by evaporation method and sputtering (Bozzola, 2007).

\section{Enzymatic production of $A$. niger}

Aspergillus strains were grown on PDA medium at $25^{\circ} \mathrm{C}$ for 3 days. Then 5 -mm mycelium disks from young fungi cultures were placed in $250 \mathrm{~mL}$ Erlenmeyer flasks containing $50 \mathrm{~mL}$ of potato dextrose (PD) broth according to CuervoParra et al. (2011) at a concentration of 25, 50, 100 and $200 \mathrm{~g} \mathrm{~L}^{-1}$ glucose, respectively. Erlenmeyer flasks were maintained at $25^{\circ} \mathrm{C}$ for 7 days under constant agitation at $120 \mathrm{rpm}$. Biomass was measured by dry weight (Collins et al., 1995).

\section{Biomass quantification as dry matter}

A spore suspension $\left(1 \times 10^{6}\right.$ spores $\left.\mathrm{mL}^{-1}\right)$ was prepared in a sterile solution of Tween 20 at a concentration of $2 \%$ and collected on a cellophane sheet in 168 Petri dishes containing the culture medium (Arévalo et al., 2005). The amount of biomass was determined at different times for each culture medium concentration $(25,50,100$ and $200 \mathrm{~g} \mathrm{~L}^{-1}$ glucose). The cellophane sheet containing the mycelium was dried in an oven at $60^{\circ} \mathrm{C}$ for $24 \mathrm{~h}$, and stored in desiccators for 24 h. Subsequently, samples were weighed on an analytical balance. The sample was obtained by the difference in dry weight and the result was expressed as gram of dry matter (g DM).

\section{Enzyme assays}

Extracts were filtered using Whatman paper filter No. 1. Mycelium disc ( $5 \mathrm{~mm})$ of $A$. niger were inoculated in $250 \mathrm{~mL}$ Erlenmeyer flasks containing $50 \mathrm{~mL}$ of minimal medium (CuervoParra et al., 2011), and the flasks were incubated for $144 \mathrm{~h}\left(250 \mathrm{rpm}, 30^{\circ} \mathrm{C}\right)$. Xylanase activity was determined according to Rawashdeh et al. (2005). Xylan was used as substrate; one unit of enzyme activity was defined as the amount of enzyme required to release $1 \mu \mathrm{mol}$ of reducing sugar (using xylose as a standard) per $\mathrm{mL}$ per min. Protease activity was measured using the method described by Kunitz (1946). The enzyme activity was defined as the amount of enzyme required to release $1 \mu \mathrm{g}$ of tyrosine per $\mathrm{mL}$ per min. Amylase activity was measured using the method described by Sugita et al. (1997). The enzyme activity was defined as the amount of enzyme required to hydrolyze 1 mole of glucose in 1 minute (AU $\mathrm{min}^{-1}$ ) under constant experimental conditions. Cellulase activity was measured using the method described by Zhang et al. (2006). The enzyme activity was defined as the amount of enzyme present capable of releasing one $\mu \mathrm{g}$ of glucose $\mathrm{h}^{-1}\left(\mu \mathrm{g} \mathrm{h}, 1 \mathrm{~mL}^{-1}\right)$. Lipase activity was measured using the method described by Nawani et al. (1998). The enzyme activity was defined as the amount of enzyme that produced $1 \mathrm{mg}$ of $p$-nitrophenol per $\mathrm{mL}$ per $\mathrm{mL}$. Enzymatic activities were measured every $24 \mathrm{~h}$. Statistical analysis was done as described above.

\section{RESULTS AND DISCUSSION}

\section{Morphological analysis}

The Aspergillus strains grown on PDA medium showed a colony diameter of 66-70 $\mathrm{mm}$, with an initial growth of white color, which with time acquires a black coloration due to the production of spores (Fig. 1a). These observations 

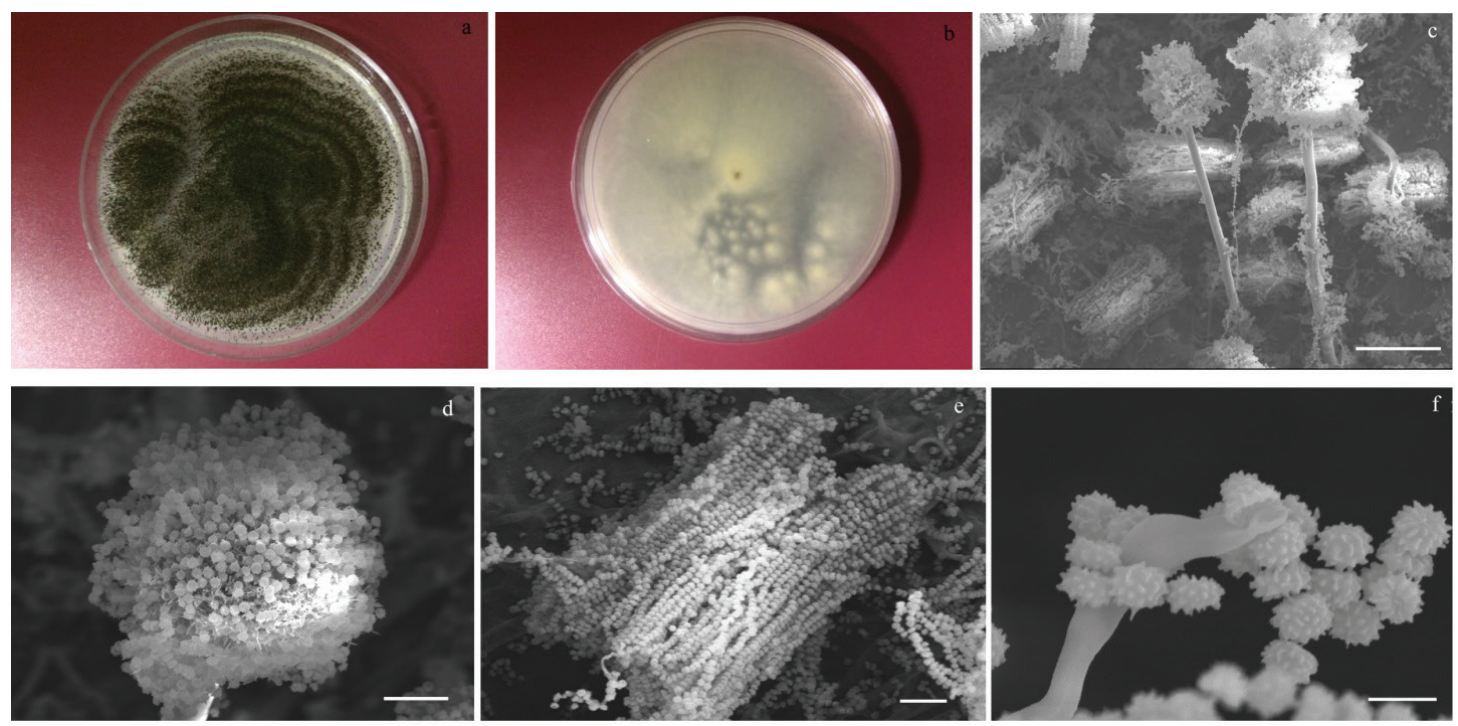

Fig. 1. Aspergillus niger morphology. (a-b) colonies on PDA; a) top view of the fungus; $b$ ) fungus culture viewed from below the Petri dish; (c-f) fungi viewed by SEM c) conidiophores, bar = $100 \mu \mathrm{m}$; d) vesicle, $b a r=20 \mu \mathrm{m} ; \mathrm{e})$ chain of conidia, $b a r=20 \mu \mathrm{m} ; \mathrm{f})$ conidia, bar $=5 \mu \mathrm{m}$.

Fig. 1. Morfología de Aspergillus niger. (a-b) colonias en PDA; a) hongo visto en la parte superior; b) cultivo de hongos visto por debajo de la placa de Petri; (c-f) hongos vistos por SEM; c) conidióforos, barra $=100 \mu \mathrm{m} ; \mathrm{d}$ ) vesícula, barra $=20 \mu \mathrm{m}$; e) cadena de conidios, barra $=20 \mu \mathrm{m}$; f) conidios, bar $=5 \mu \mathrm{m}$.

coincide with those reported by other authors for A. niger strains grown in Malt Extract Agar (Silva et al., 2011), and Czpeck Yeast Agar (Araujo-Blanco et al., 2016). The reverse side of the colony was colorless to light yellow (Fig. 1b). The conidial heads were dark brown to black, biseriate, conidia globose, irregularly rough to finely rough, crests and grooves $2.9-4 \mu \mathrm{m} \pm 0.7$. The conidial heads that present only phialides are characterized as uniseriate, whereas if they have metula and phialides they are biseriate (Cruz, 2014). The hyphae are well developed, profusely branched, septate and hyaline near the apex (Vega et al., 2012). As a general rule the cells are multinucleated, with three well-defined zones (Nithiyaa et al., 2012). Of these, the first is the foot cell that joins the fruiting body with the somatic mycelium, which may or may not be septate (Eltem et al., 2004). The second zone is the conidiophore, with cylindrical and elongated shape, which projects the reproductive mycelium out of the somatic mycelium (Samson and Varga, 2007) in aerial form with negative geotropism (Araujo-Blanco et al., 2016). The young mycelium produces conidiophores in abundance that arises solitary from the somatic hyphae (AraujoBlanco et al., 2016). The hyaline or pigmented conidiophores are long, erect, each ending in a bulbous head called vesicle, subglobally shaped, 254-300 $\mu \mathrm{m}( \pm 27)$ in diameter (Fig. 1c).

However, this structure can measure up to
2500 microns (Gautam and Bhadauria, 2012). The third zone is the vesicle, which develops at the apical end with a variable shape ranging from spherical, hemispherical, globular, subglobose or ellipsoidal (Abarca, 2000). A large number of conidiogenic cells are produced on the surface of the multinucleated vesicle as it develops, and are thus seen as radiated conidial heads. The vesicles of the conidiophore showed a thick, rounded, globose to subglobose wall (Colin et al., 2013), between 30-112 $\mu \mathrm{m}$ (Fig. 1d). Metula present between 10-20 × 3-6 $\mu \mathrm{m}$. Conidiogenic cells, either primary or secondary, are typical phialides, ranging from 7-10 $\times 3-4 \mu \mathrm{m}$; as they reach maturity, these produce conidia one after another, in chains (Fig. 1e). Conidia are globular, 2.9-4 $\mu \mathrm{m}$ in diameter, ornate, brown, with rough walls, which form at the end of the tubular phialides (Fig. 1f). These asexual spores produce rosaries or chains of conidia (Cruz, 2014). By means of these structures, these fungi propagate clonally if environmental and nutritional conditions are favorable for their growth (Araujo-Blanco et al., 2016). As conidiophores and conidia are produced abundantly, their color is predominant in pigmentation of the colony, being black or brown. These observations allowed the identification of isolated strains within the $A$. niger species and are in agreement with Abarca (2000) and Vega et al. (2012). 


\section{Molecular characterization and phylogenetic analysis}

Amplification of ITS I/5.8s/ITS II region of the ribosomal DNA (rDNA) isolated from each strain was carried out with primers ITS1 and ITS4 (Samson et al., 2014). In this study, 11 sequences of fungi were amplified; these regions had a variable size ranging from 530 to 609 base pairs (bp). Sequences were aligned using the Basic Local Alignment Search Tool (Morgulis et al., 2008) with other sequences of Aspergillus genus from GenBank, reaching a sequence identity in the range of 98 and $99 \%$. Finally, a phylogenetic tree was constructed for the characterized strains and the phylogenetically related fungi.

The results obtained with the BLASTN program confirm that strains HT-ITV5, HT-ITV24, HT-ITV53, HT-ITV42, HT-ITV21, HT-ITV47, HTITV28, HT-ITV52, HT-ITV39, HT-ITV49, and HTITV18, deposited in the NCBI GenBank databases with the accession number KP963950, KF010173, K096352, KP963947, KF010172, KP963948, KF010174, KP963951, KP963946, KP9633949 and KF010171, correspond to new strains of $A$. niger for Mexico.

The sequences examined in this study for the ITS I/5.8s/ITS II region, for the cocoa $A$. niger strains and other related sequences from NCBI GenBank databases had a length ranging from 413 to 1452 $\mathrm{bp}$, and a length of $1758 \mathrm{bp}$ of consensus region for the alignment sequences. Between ITS I and ITS II regions, the ITS I region was the most conserved Aspergillus sequence used in this study. For the analysis of $5.8 \mathrm{~S}$ subunit, it was observed that all species of Aspergillus were highly conserved with only a few base changes (insertions, deletions and substitutions) in the sequences of $A$. glaucus, $A$. niger, A. nidulans, A. ochraceoroseus, A. cremeus, A. flavipes, A. flavus and $A$. versicolor strains. On the other hand, 18S and 28S subunits showed higher variations but limited to point mutations, insertions or deletions, predominantly among isolates of A. fumigatus, A. sparsus, A. niger, A. candidus and $A$. flavus. Deletions, insertions and base substitutions varied greatly within the ITS regions, especially in the ITS II, although many conserved regions were present in the ITS region I and ITS II. In general, the length of the sequences of the ITS I and ITS II regions was highly conserved in all species of Aspergillus, with limited variations to the few base change.

Phylogenetic analysis of $A$. niger cocoa sequences and 49 other representative Aspergillus sequences from GenBank were used to generate a tree by the Neighbour-Joining (NJ) method, forming three major clades (I, II, and III) based on sequencing of the ITS regions of rDNA sequences (Fig. 2). To be able to infer phylogenetic relationships, the $\mathrm{NJ}$ tree was rooted with Bacillus subtilis (AB474001, KM659218) and Lactobacillus fermentum (AF382391) GenBank sequences as outgroup. The optimal tree with the sum of branch length $=2.04833715$ is shown. The percentage of times in which the associated taxa were grouped together in the bootstrap test (1000 replications) is shown next to the branches in the phylogenetic tree. The three main clades represented by different sequences of species of Aspergillus genus were supported by high bootstrap values. Clade I could be subdivided into four subclades (I, II, III, and IV).

At the top of the subclade I, it can be observed that the Mexican cocoa strains were phylogenetically related to the NCBI GenBank sequences of $A$. niger from India (KY657577), Mozambique (AM745113), Portugal (KX897144), and Spain (AY656630). Considering the high bootstrap value obtained during the construction of the phylogenetic tree, these strains were easily distinguishable from the other Aspergillus sequences branches in other clades.

The subclade II includes sequences belonging to the Sections Sparsi and Wentii isolated from USA (EF661184, EF661183), France (FR670319), Ecuador (KX712427) and Brazil (KP691043). Subclade III comprises a large group, belonging to the Sections Aspergillus, Ornati, Cervini, Clavati, Fumigati, Candidi and Restricti, which include the species $A$. glaucus, A. ornatus, A. cervinus, $A$. clavatus, A. fumigatus, $A$. candidus, and $A$. restrictus isolated from different hosts and geographic regions (KX394538, KF298065, KM232504, EF669704, EF669705, HQ608146, AJ874118, JQ316526, KF669481. HQ844676, GU566242, JX421732, KP724998, JQ781823, LT626947, JQ724415, NR_135333, JX156352). On the other hand, subclade IV includes sequences for species of the Sections Terrei (KR610362, KF364668), Flavipedes (GU566209, JF817254), Circumdati (HQ843030, DQ336712), Cremei (EF652148, NR_137455) and Flavi (AM745114, FJ878656, JQ316529), supported with high bootstrap values, $\geq 84$ (Fig. 2).

The other two clades of the phylogenetic tree comprise species of the Sections Ochraceoreosei (NR_135381, JN217239), for clade II and species of the Sections Nidulantes, Versicolor and Usti for clade III, isolated from different host and geographic regions of the American continent (KR012899), Europe (KM063206, EU982032, FJ878645, KX690140, HE962600), Oceania (KF020313) and Asia (HQ116387, JF817276).

The clades generated in the phylogenetic analysis reveal the formation of groups corresponding to their morphologic characteristics, allowing for the identification of 


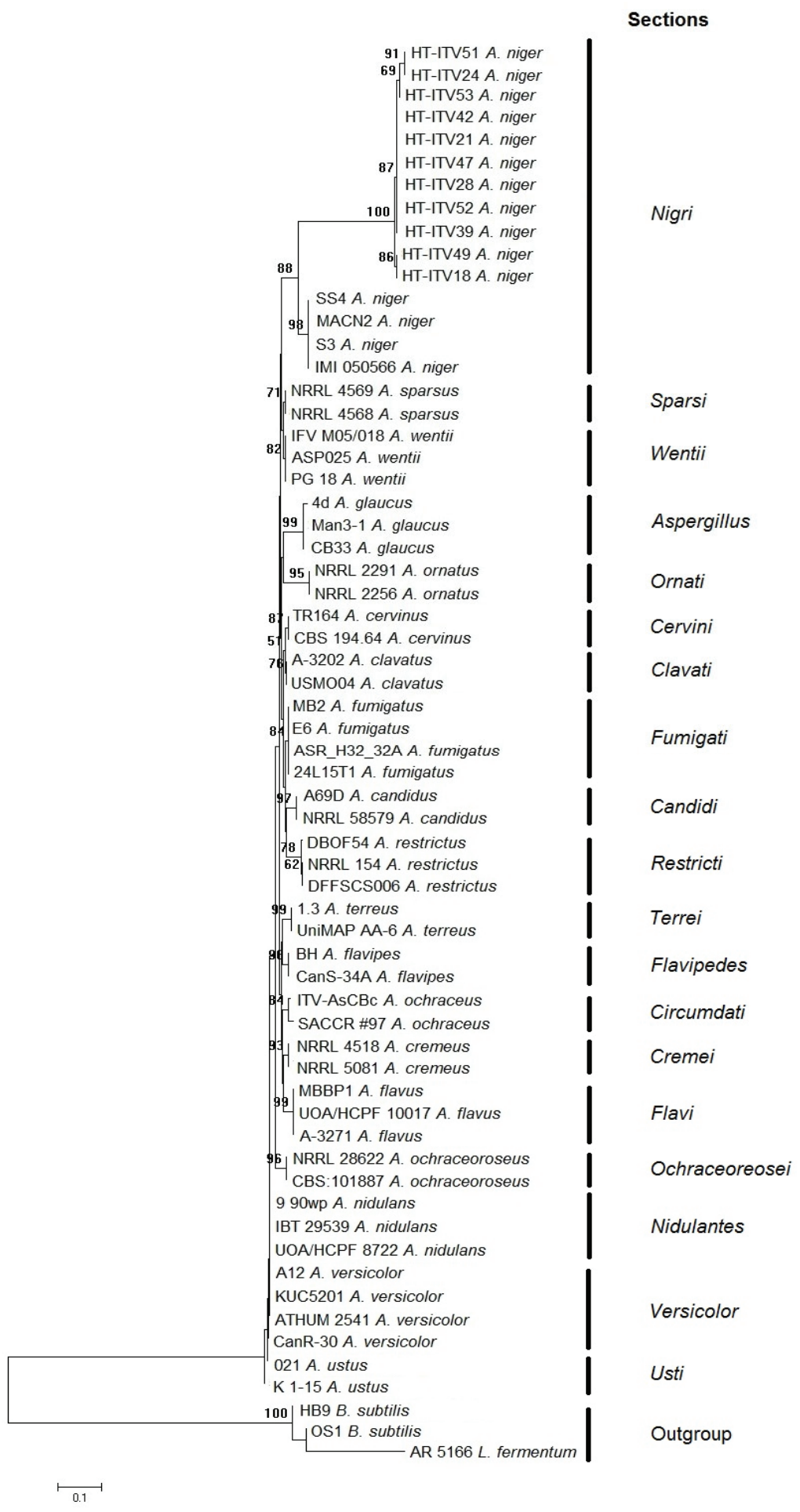

Fig. 2. Neighbour-Joining tree derived from fungal ITS sequence data. Numbers on nodes are bootstrap values.

Fig. 2. Árbol filogenético generado por el método Neighbour-Joining derivado de datos de secuencias de ITS de hongos. Los números en los nodos son valores de bootstrap. 
the species within each of the Sections. Similarly, the use of the ITS regions of the rDNA genes allowed the comparison of isolated cocoa strain sequences with other sequences related from other GenBank specimens. This result confirms that the strains identified as $A$. niger may belong to different specimens of these species, based on bootstrap values that support these alignments. The morphological differences constitute an important tool for the characterization of new species, even in members of the same clade (Silva et al., 2011). On the other hand, mutation and recombination are a major source of genetic variation in fungal pathogens (Zhang et al., 2013). Recombination, specifically, allows horizontal gene transfer or lateral gene transfer in fungi species (Fitzpatrick, 2012). Furthermore, within a species, genes flow between populations; propagules which diffuse from one epidemiological area to another and from one population of closely related interbreeding organisms to the next add to this process. This would explain the observed differences between the cocoa $A$. niger sequences isolated in this study and the GenBank sequences of the same species compared.

\section{Confrontation experiments}

The antagonistic ability of T. asperellum VSL80 strain was tested against $A$. niger cocoa strains by confrontation experiments in dual culture. The digital images taken on 7 days of incubation (Fig. 3) were used to calculate the BCIs values.

A characteristic that gives an advantage to an antagonistic microorganism over phytopathogens is its ability to grow rapidly and compete for space and nutrients with pathogens (Benítez et al., 2004). In this sense, after 7 days of incubation, T. asperellum VSL80 grew rapidly on the culture medium in most of the Petri dishes. However, the BCI values of $T$. asperellum VSL80 against the $A$. niger strains studied ranged from $15.36 \pm 0.150$ and $88.71 \pm 0.015$, respectively (Table 1 ).

The results obtained in this study showed a variable effect for the antagonistic interaction observed between $T$. asperellum VSL80 strain and $A$. niger strains confronted. This behavior has been observed in other T. asperellum strains. El_Komy et al. (2015) observed that 30 strains of $T$. asperellum confronted with four Fusarium oxysporum strains, which represent a major limiting factor of tomato plantations, showed moderate inhibition of the pathogen growth of 61 to $65 \%$, whereas only 6 of these strains caused a significant reduction of Fusarium growth $(68-71 \%)$. Other authors reported a variable antagonistic effect of Trichoderma spp. against $A$. niger strains derived from jack bean (Canavalia ensiformis) (Amorim and Pascholati, 2011). On the other hand, a commercial strain of T. asperellum (Qualiti WG®, Nova city, Brazil) presented a variation in their antagonistic effect of $66.6 \%$ against $A$. niger strain isolated from jack beans (Lima et al., 2016). The results obtained between $T$. asperellum and $A$. niger interaction coincide with these studies and with numerous previous studies (Tondje et al., 2007; Marcello et al., 2010; de los Santos-Villalobos et al., 2013). In this study, the interaction of $T$. asperellum VSL80 strain with $A$. niger isolates resulted in significantly different amounts of inhibition of the pathogen confronted. The most susceptible $A$. niger isolates

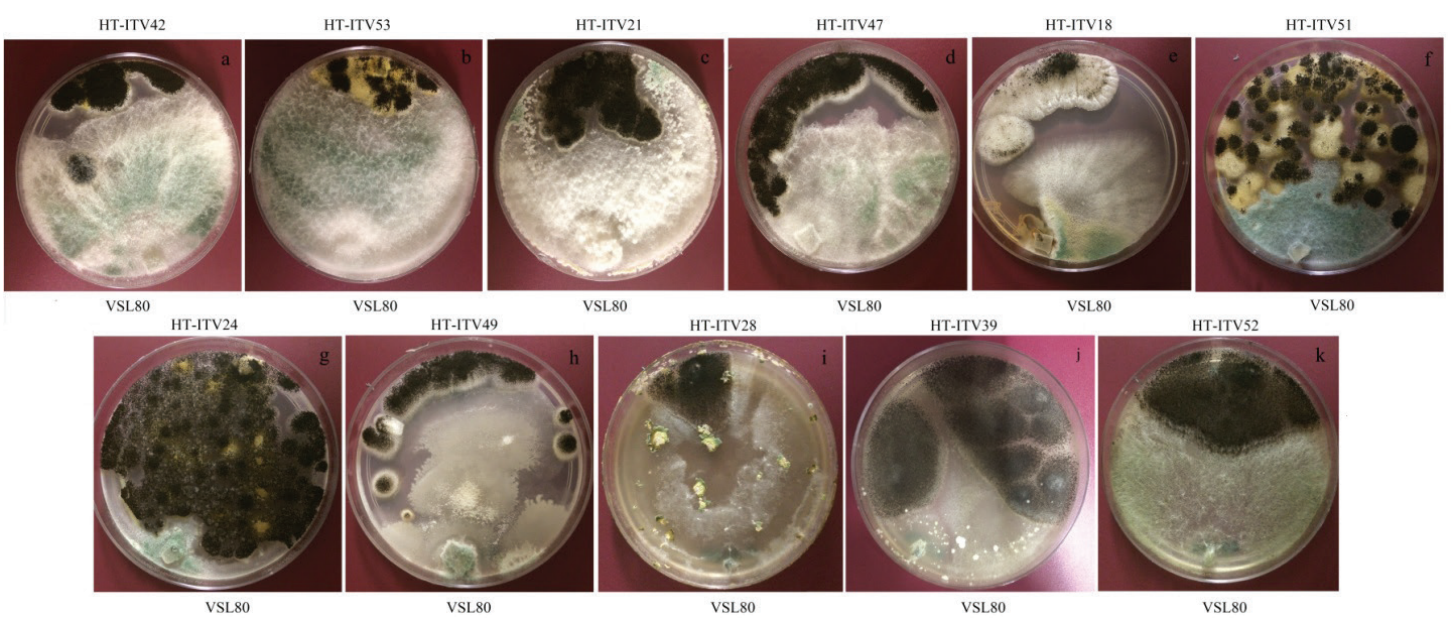

Fig. 3. Digital images taken at 7 days of confrontation of T. asperellum VSL80 against $T$. cacao phytopathogenic fungi (A. niger) on PDA medium.

Fig. 3. Imágenes digitales tomadas a los 7 días de confrontación de T. asperellum VSL80 contra hongos fitopatógenos de T. cacao (A. niger) en medio PDA. 
Table 1. Biocontrol index (BCI) of T. asperellum VSL80 against $A$. niger strains.

Tabla 1. Índice de biocontrol (BCI) de T. asperellum VSL80 contra cepas de A. niger.

\begin{tabular}{lcc}
\hline Phytopathogenic fungi & Strain number & $\mathbf{B C I} \pm \mathbf{S D}^{*} \mathbf{( \% )}$ \\
\hline A. niger & HT-ITV42 & $81.04 \pm 0.014$ \\
A. niger & HT-ITV53 & $82.41 \pm 0.015$ \\
A. niger & HT-ITV21 & $75.51 \pm 0.147$ \\
A. niger & HT-ITV47 & $62.29 \pm 0.345$ \\
A. niger & HT-ITV18 & $48.94 \pm 0.356$ \\
A. niger & HT-ITV51 & $15.36 \pm 0.150$ \\
A. niger & HT-ITV28 & $70.21 \pm 0.014$ \\
A. niger & HT-ITV49 & $88.71 \pm 0.015$ \\
A. niger & HT-ITV24 & $27.49 \pm 0.225$ \\
A. niger & HT-ITV39 & $34.96 \pm 0.159$ \\
A. niger & HT-ITV52 & $66.74 \pm 0.159$ \\
\hline
\end{tabular}

* Standard deviation.

(over $>70 \%$ growth inhibition) were the strains HT-ITV49, HT-ITV53, HT-ITV42, HT-ITV21 and HT-ITV28, while strains HT-ITV51 and HT-ITV24 were the least inhibited (Table 1). These results are consistent with those obtained in a study conducted by Markovich and Kononova (2003), who reported that Trichoderma mycoparasite capacity varies between isolates and species tested. In this sense, some pathogenic strains of fungi of the genus Fusarium have been reported to have deleterious effects on Trichoderma spp., by producing mycotoxins that would have a direct antagonistic activity that can affect Trichoderma genes related to the process of mycoparasitism (El_Komy et al., 2015). Other authors reported the presence of protein in the cell wall of some pathogenic fungi, which would make these strains more resistant to the mycoparasitism exerted by Trichoderma (Sivan and Chet, 1989).

Subsequently, SEM photographs of the interaction zone between Trichoderma and A. niger were taken at 31 days of incubation to evaluate the mycoparasitism exerted by $T$. asperellum VSL80 on the A. niger strains. An initial rapid increase of the Trichoderma VSL80 colonies was observed in most cases at the first 7 days, while the areas did not change considerably during the following periods in the interaction with the strains HT-ITV51, HT-ITV52 and HT-ITV53 of $A$. niger. On the other hand, a progressive inhibition zone produced by $T$. asperellum VSL280 against A. niger HT-ITV42, HT-ITV47, HT-ITV18 and HT-ITV49 strains was observed. In addition, a clear mycoparasitism effect with the formation of pustules in the strains HT-ITV21, HT-ITV28 and HT-ITV39 of $A$. niger was detected. In these isolates, an overgrowth and sporulation of $T$. asperellum VSL80 were observed on the colonies of the pathogen (Fig. 4). Meanwhile, the interaction between strains HT-ITV51 and HTITV24 of $A$. niger with T. asperellum VSL80 strain produced less inhibition. The mycoparasitism effect of T. asperellum VSL80 on morphological deformations and disorganization in the structure of A. niger abnormal hyphal morphology and lysis of mycelia was observed on the interaction areas (Fig. 5). During the confrontation, there is secretion of hydrolytic enzymes such as chitinases and $\beta$-1, 3-glucanases, which hydrolyze the major structural components of the cell walls of pathogenic fungi (Qualhato et al., 2013). The relationship between the antagonistic capacity and the production of hydrolytic enzymes by each Trichoderma isolate is fundamental during mycoparasitism (El_Komy et al., 2015).

\section{Biomass and enzyme production}

In general, $A$. niger strains rapidly reached their maximum growth at $168 \mathrm{~h}$ in the tested conditions. According to Meijer et al. (2011), all A. niger strains have similar growth profiles on monosaccharide substrates, but they grow best on starch and pectin. Therefore, the growth of $A$. niger strains in a defined media can be used as a first step in the identification and isolation, since these fungi do not differentiate among strains of the same isolated species.

\section{Biomass determination in dry weight}

Biomass quantity is an essential parameter in kinetic studies and for the characterization of the optimum growth of different fungi. The content of the different cell components can change markedly in fungi depending on fungal species, growth conditions, culture age and chemical composition in the media (VanderMolen et al., 2013). In this study, the microbial biomass is a fundamental variable expressed as dry weight, 


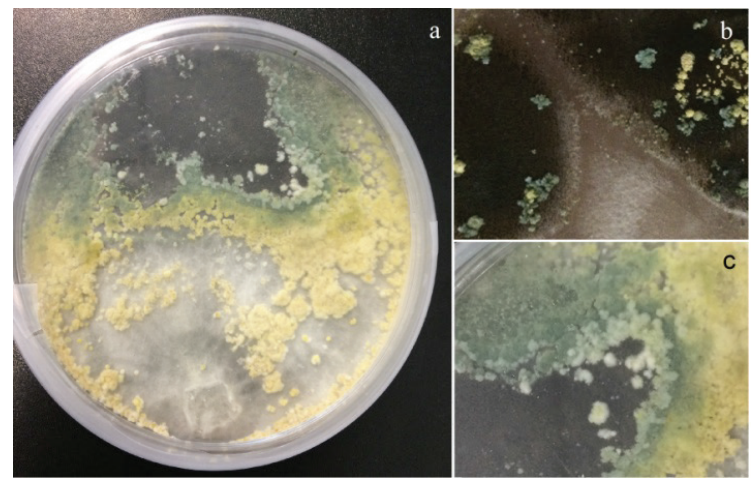

Fig. 4. Morphology of T. asperellum VSL80 strain at 31 days of interaction with A. niger HT-ITV21 strain (a); production of green and yellow pustules on the colonies of the A. niger HT-ITV39 (b) and HT-ITV21 strains (c) on PDA medium.

Fig. 4. Morfología de la cepa VSL80 de T. asperellum a los 31 días de interacción con la cepa A. niger HT-ITV21 (a); producción de pústulas verdes y amarillas en las colonias de las cepas $A$. niger HT-ITV39 (b) y HT-ITV21 (c) en medio PDA.

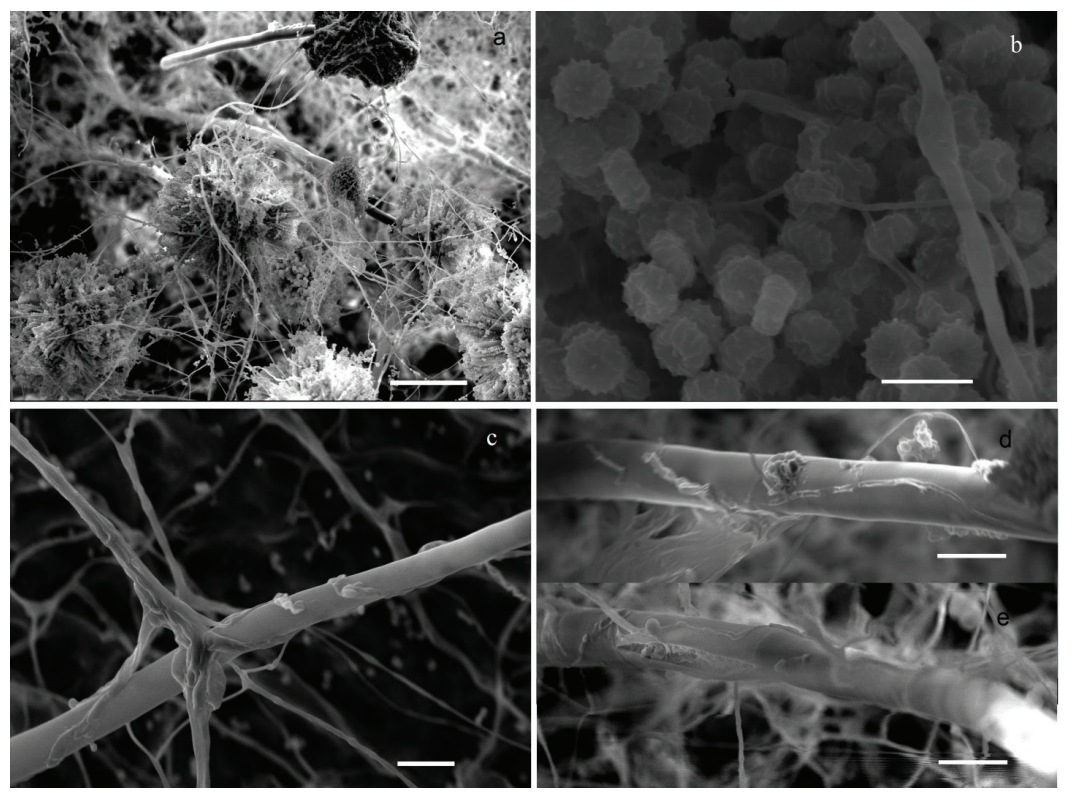

Fig. 5. Scanning electron microscopy micrographs (a, b, c, d and e) showing the mycoparasitic effect by T. asperellum VSL80 on PDA medium: (a) Mycelia of $A$. niger parasitized by T. asperellum colonies, $\mathrm{bar}=100 \mu \mathrm{m}$; (b) Mycoparasitism by apresorious structures on conidia of $A$. niger by T. asperellum, bar = $5 \mu \mathrm{m}$; (c) Mycoparasitism by envelopment of $A$. niger conidiophore by $T$. asperellum hyphae, bar $=20 \mu \mathrm{m}$; (d-e) Structural damage caused in conidiophores of $A$. niger by $T$. asperellum enzymes, bar $=20 \mu \mathrm{m}$.

Fig. 5. Micrografías de microscopía electrónica de barrido $(\mathrm{a}, \mathrm{b}, \mathrm{c}, \mathrm{d}$ y e) que muestran el efecto micoparasitario de T. asperellum VSL80 en medio PDA: (a) Micelios de A. niger parasitados por colonias de T. asperellum, barra $=\mathbf{1 0 0} \mu \mathrm{m}$; (b) Micoparasitismo por estructuras apresorios en conidios de $A$. niger por T. asperellum, barra $=5 \mu \mathrm{m}$; (c) Micoparasitismo por envolvimiento del conidióforo de $A$. niger por hifas de T. asperellum, barra $=20 \mu \mathrm{m}$; (d-e) Daño estructural causado en conidióforos de $A$. niger por enzimas de T. asperellum, barra $=20 \mu \mathrm{m}$. 
which is important for the determination of growth kinetics. In this sense, a direct relationship was found between the dextrose concentration and dry biomass obtained (Fig. 6). In addition, it has been widely reported that $A$. niger is equipped for utilizing sugar as the sole source of carbon. The growth and allocation of $A$. niger response to saccharides generally includes increasing entire colonies, biomass, and reducing the level of carbohydrates in the surrounding environment (Gupta and Neha, 2012).

\section{Xylanase production in liquid fermentation}

The highest xylanase production by $A$. niger strains was observed at $96 \mathrm{~h}$ (1.128 $\mathrm{U} \mathrm{mL}^{-1}$ protein). The $\beta-1,4$-xylans are heteropolysaccharides consisting of $\beta-1,4$-xylopyranosyl residues, whose groups (such as D-glucuronic acid, L-arabinose, $p$-coumaric acid and ferulic acid) are attacked by enzymes capable of degrading xylan (Seidl et al., 2006). The xylanases production has been studied using different substrates: glucose, rice bran $(1.0 \%, 0.5 \%)$, rice straw $(1.0 \%$, $0.5 \%)$, coarse sugarcane bagasse $(1.0 \%, 0.5 \%)$, fine sugarcane bagasse $(1.0 \%, 0.5 \%)$, corncob $(1.0 \%, 0.5 \%)$, wheat bran $(1.0 \%, 0.5 \%)$, xylan (oat spelt; $1.0 \%, 0.5 \%$ ), xylan (birchwood; $1.0 \%$, $0.5 \%)$, corncob $(0.5 \%)+$ fine sugarcane bagasse $(0.5 \%)$, wheat bran $(0.5 \%)+$ fine sugarcane bagasse $(0.5 \%)$, wheat bran $(0.5 \%)+$ corncob (0.5\%; De Alencar-Guimaraes et al., 2013) and birchwood xylan (Peixoto-Nogueira et al., 2009).
In addition, there are many studies on xylanase production using several Aspergillus species, for example, Aspergillus terreus, A. niger, A. terricola, A. foetidus, A. niveus, A. ochraceus and A. ficuum. De Alencar-Guimaraes et al. (2013) observed that $1 \%$ wheat bran was the best carbon source for xylanase production by $A$. niger $\left(12.76 \mathrm{U} \mathrm{mg}^{-1}\right.$ of protein), followed by fine sugarcane bagasse $0.5 \%$ (10.64 $\mathrm{U} \mathrm{mg}^{-1}$ of protein) and corncob 1\% (10.00 $\mathrm{U} \mathrm{mg}^{-1}$ of protein). For $A$. flavus, the xylanase production was better induced by wheat bran at a concentration of $1 \%$ and $0.5 \%$ (8.03 and $8.70 \mathrm{U}$ $\mathrm{mg}^{-1}$ of protein, respectively), followed by fine sugarcane bagasse of $1 \%$ (7.68 $\mathrm{U} \mathrm{mg}^{-1}$ of protein).

The interactions that occur between two microorganisms during mycoparasitism result in the degradation of structures of the cell wall of the pathogenic fungus by the antagonistic microorganism of the genus Trichoderma (Peberdy, 1990). From Table 2, it can be observed that all strains of $A$. niger grown in broth PD with sucrose as source of carbon, produced several hydrolytic enzymes in the culture medium. This showed their maximum enzymatic activity at different times. This result could explain the low $\mathrm{BCI}$ observed in some $A$. niger strains confronted with T. asperellum.

\section{CONCLUSIONS}

The morphological and molecular characterization of the strains studied in this

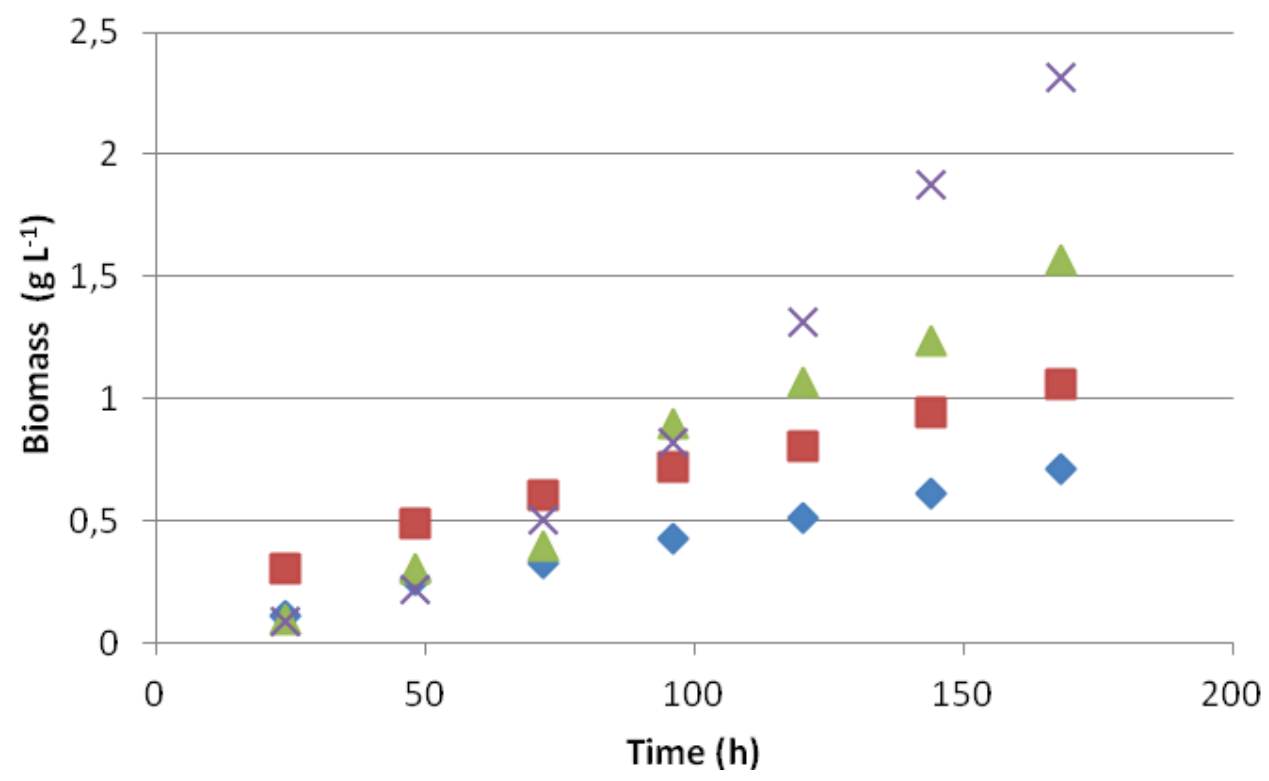

Fig. 6. Dry biomass of $A$. niger cultivation at different dextrose concentration $(\diamond 25 \mathrm{~g}=50 \mathrm{~g} \Delta 100 \mathrm{~g}$ and $\times 200 \mathrm{~g}$ ).

Fig. 6. Biomasa seca del cultivo de A. niger a diferentes concentraciones de dextrosa $(\diamond 25 \mathrm{~g}=50 \mathrm{~g}$ $\Delta 100 \mathrm{~g}$ y $\times 200 \mathrm{~g})$. 
Table 2. Enzymatic activities of $A$. niger strains growth in PD broth as carbon source. Tabla 2. Actividades enzimáticas de cepas de $A$. niger cultivadas en caldo PD como fuente de carbono.

\begin{tabular}{|c|c|c|c|c|c|c|}
\hline \multirow[b]{2}{*}{ Hours } & \multirow[b]{2}{*}{ Protein $\mathrm{mg} \mathrm{mL}^{-1}$} & \multicolumn{3}{|c|}{ Enzymatic activities $\pm \mathrm{SD}^{*}\left(\mathrm{U} \mathrm{mL}^{-1}\right)$} & \multirow[b]{2}{*}{ Amylases } & \multirow[b]{2}{*}{ Lipases } \\
\hline & & Xylanases & Proteases & Cellulases & & \\
\hline 0 & 0 & 0.00 & 0 & 0 & 0 & 0 \\
\hline 24 & $44.69 \pm 1.7$ & $0.383 \pm 0.012$ & $21.48 \pm 0.2$ & $11.79 \pm 0.8$ & $7.29 \pm 0.1$ & $0.21 \pm 0.01$ \\
\hline 48 & $152.47 \pm 2.1$ & $0.785 \pm 0.007$ & $45.23 \pm 0.3$ & $5.86 \pm 0.1$ & $11.19 \pm 0.05$ & $0.55 \pm 0.006$ \\
\hline 72 & $214.14 \pm 6.1$ & $0.882 \pm 0.021$ & $39.08 \pm 1.7$ & $5.15 \pm 0.2$ & $9.69 \pm 0.1$ & $0.89 \pm 0.006$ \\
\hline 96 & $301.36 \pm 8.8$ & $1.128 \pm 0.006$ & $28.52 \pm 0.5$ & $2.73 \pm 0.1$ & $7.72 \pm 0.1$ & $1.15 \pm 0.002$ \\
\hline 120 & $359.97 \pm 6.6$ & $0.768 \pm 0.061$ & $15.72 \pm 0.2$ & $1.62 \pm 0.04$ & $3.89 \pm 0.2$ & $0.74 \pm 0.01$ \\
\hline 144 & $425.25 \pm 3.6$ & $0.256 \pm 0.007$ & $7.32 \pm 0.1$ & $0.60 \pm 0.02$ & $1.66 \pm 0.7$ & $0.27 \pm 0.17$ \\
\hline
\end{tabular}

* Standard deviation.

work confirm the presence of the Aspergillus niger fungi in cocoa plants. It represents the first report of this fungus as a cocoa pathogen. In addition, information obtained on the BCI may be important for the development of strategies for the prevention and control of this fungus. Trichoderma isolates from cocoa showed antagonistic activity. The enzymatic activity of A. niger during mycoparasitism by T. asperellum VSL80 could explain the low BCI observed in some $A$. niger strains confronted with $T$. asperellum. Finally, the results obtained in this study for the xylanolytic enzyme production by $A$. niger cocoa strains through solid medium and submerged fermentation culture production indicate that this fungus could be used in the industry to obtain xylanases.

\section{LITERATURE CITED}

Abarca, L.M. 2000. Taxonomía e identificación de especies implicadas en la aspergilosis nosocomial. Rev. Iberoam. Micol. 17:S79-S84.

Amorim, L., and S.F. Pascholati. 2011. Ciclos das relações patógeno-hospedeiro. p. 59-100. En L. Amorim, J.A.M Rezende, F. Bergamin (eds.) A. Manual de Fitopatologia: Princípios e Conceitos. 4. ed. São Paulo-SP: Agronômica Ceres, Brasil.

Araujo-Blanco, J., Y. Rojas, B. Depool, A. Antequera, J. Rodríguez, and F. Yegres. 2016. Microanálisis de una cepa de Aspergillus niger biocatalizadora de hidrocarburos policíclicos aromáticos HPA. Acta Microscopica. 25:98110.

Arévalo, G.E., B.C. Ortiz, C.L. Zúñiga, and V.J. Gonzáles. 2005. Hoja Técnica No. 51. Selección de plantas de cacao resistentes a la Moniliasis usando savia del floema y fluidos embriónicos de frutos jóvenes. Manejo Integrado de Plagas y Agroecología (Costa Rica) 76:86-88.
Benítez, T., A.M. Rincón, M.C. Limón, and A.C. Codón. 2004. Biocontrol mechanisms of Trichoderma strains. Int. Microbiol. 7:249-260.

Bozzola, J.J. 2007. Conventional specimen preparation techniques for scanning electron microscopy of biological specimens. p. 449466. En J. Kuo (ed.) Electron Microscopy: Methods and Protocols. 2nd. ed. Humana Press Inc., Totowa, New Jersey, USA.

Bradford, M.M. 1976. A rapid and sensitive method for the quantitation of microgram quantitites of protein utilizing the principle of protein-dye binding. Anal. Biochem. 72:248254. doi:org/10.1016/0003-2697(76)90527-3.

Colin, V.L., M.D. Baigorí, and L.M. Pera. 2013. Tailoring fungal morphology of Aspergillus niger MYA 135 by altering the hyphal morphology and the conidia adhesion capacity: biotechnological applications. AMB Express 3:1-13. doi: 10.1186/2191-0855-3-27.

Collins, C., P. Lyne, and J. Grande. 1995. Microbiological methods. Ed. Butter-WothHeinemann, Great Britain.

Cuervo-Parra, J.A., M. Ramírez-Suero, V. Sánchez-López, and M. Ramírez-Lepe. 2011. Antagonistic effect of Trichoderma harzianum VSL 291 on phytopathogenic fungi isolated from cocoa (Theobroma cacao L.) fruits. Afr. J. Biotechnol. 10:10657-10663. doi:10.5897/ AJB11.1333.

Cuervo-Parra, J.A., V. Sánchez-López, T. Romero-Cortes, and M. Ramírez-Lepe. 2014. Hypocrea/Trichoderma viridescence ITV43 with potential for biocontrol of Moniliophthora roreri Cif \& Par, Phytophthora megasperma and Phytophthora capsici. Afr. J. Microbiol. Res. 8:1704-1712. doi:10.5897/AJMR2013.6279.

Cruz, R. 2014. Guía para el diagnóstico de laboratorio de enfermedad fúngica invasora por hongos filamentosos. Rev. Chilena Infectol. 31:173-179. doi:10.4067/S071610182014000200008 . 
De Alencar-Guimaraes, N.C., M. Sorgatto, S. de C. Peixoto-Nogueira, J.H.A. Betini, F.F. Zanoelo, M.R. Marques, et al. 2013. Bioprocess and biotecnology: effect of xylanase from Aspergillus niger and Aspergillus flavus on pulp biobleaching and enzyme production using agroindustrial residues as substract. SpringerPlus. 2:380. doi:10.1186/2193-18012-380.

De los Santos-Villalobos, S., D.A. Guzmán-Ortiz, M.A. Gomez-Lim, J.P. Délano-Frier, S. deFolter, P. Sànchez-Garía, et al. 2013. Potential use of Trichoderma asperellum (Samuels, Liechfeldt et Nirenberg) T8a as a biological control agent against anthracnose in mango (Mangifera indica L.). Biol. Control 64:37-44. doi:10.1016/j.biocontrol.2012.10.006.

El_Komy, M.H., A.A. Saleh, A. Eranthodi, and Y.Y. Molan. 2015. Characterization of novel Trichoderma asperellum isolates to select effective biocontrol agents against tomato fusarium wilt. Plant Pathol. J. 31:50-60. doi:10.5423/PPJ.OA.09.2014.0087.

Eltem, R., T. Askun, S. Nermin, E.O. Taskin, and H. Efendiler. 2004. Colonial and morphological characteristics of some Aspergillus Fr.: Fr. species isolated from vineyards in Manisa and Izmir provinces (Turkey). Turk. J. Bot. 28:287-298.

Fitzpatrick, D.A. 2012. Horizontal gene transfer in fungi. FEMS Microbiol. Lett. 329:1-8. doi:10.1111/j.1574-6968.2011.02465.x.

Gautam, A.K., and R. Bhadauria. 2012. Characterization of Aspergillus species associated with commercially stored triphala powder. Afr. J. Biotechnol. 11:16814-16823. doi: 10.5897/AJB11.2311.

Gautam, A.K., S. Sharma, S. Avasthi, and R. Bhadauria. 2011. Diversity, pathogenicity and toxicology of A. niger: An important spoilage fungi. Res. J. Microbiol. 6:270-280. doi:10.3923/jm.2011.270.280.

Gupta, V.C., and S. Neha. 2012. Batch biodegradation of phenol of paper and pulp effluent by Aspergillus niger. Int. J. Chem. Eng. Appl. 3:182-186. doi: 10.7763/ IJCEA.2012.V3.183.

Izarra, L.M., L.M. Santayana, K.G. Villena, and M. Gutiérrez-Correa. 2010. Influencia de la concentración de inóculo en la producción de celulasa y xilanasa por Aspergillus niger. Rev. Colomb. Biotecnol. 12:139-150.

Kendall, J.M., and P.T. Rygiewicz. 2005. Fungalspecific PCR primers developed for analysis of the ITS region of environmental DNA extracts. BMC Microbiol. 5:1-11. doi:10.1186/1471-2180-5-28.
Kuhad, R.C., R. Gupta, and A. Singh. 2011. Microbial cellulases and their industrial applications. Enzyme Res. 2011: 280696. doi:10.4061/2011/280696.

Kunitz, M. 1946. Spectrophotometric method for the measurement of ribonuclease activity. J. Biol. Chem. 164:563-568.

Lima, M.L.P., M.C.A. Vaz, A.S. Silva, K.A. Souza, and G.I.L. Tuñon. 2016. In vitro confrontation of Trichoderma spp. isolates with phytopathogenic and non-phytopathogenic fungi. Revista de Agricultura Neotropical 3:1-8.

Marcello, C.M., A.S. Steindorff, S.P. Silva, R.N. Silva, L.A.M. Bataus, and C.J. Ulhoa. 2010. Expression analysis of the exo- $\beta-1,3-$ glucanase from the mycoparasitic fungus Trichoderma asperellum. Microbiol. Res. 165:75-81. doi:10.1016/j.micres.2008.08.002.

Martínez-Anaya, C., E. Balcázar-López, E. Dantán-González, and J.L. Folch-Mallol. 2008. Celulasas fúngicas: Aspectos biológicos y aplicaciones en la industria energética. Rev. Latinoam. Microbiol. 50:119-131.

Markovich, N.A., and G.L. Kononova. 2003. Lytic enzymes of Trichoderma and their role in plant defense from fungal diseases, a review. Appl. Biochem. Microbiol. 39:389-400.

Meijer, M., J.A.M.P. Houbraken, S. Dalhuijsen, R.A. Samson, and R.P. de Vries. 2011. Growth and hydrolase profiles can be used as characteristics to distinguish Aspergillus niger and other black aspergilli. Studies in Mycology 69:19-30. doi:10.3114/ sim.2011.69.02.

Morgulis, A., G. Coulouris, Y. Raytselis, T.L. Madden, R. Agarwala, and A.A. Schäffer, 2008. Database indexing for production MegaBLAST searches. Bioinformatics 24:1757-1764. doi:10.1093/bioinformatics/ btn322.

Mounjouenpou, P., D. Gueule, T.S.A. Maboune, B. Guyot, A. Fontana-Tachon, and J.P. Guiraud. 2012. Incidence of pod integrity on the fungal microflora and Ochratoxin-A production in cocoa. Journal of Biology and Life Science 3:254-265. doi:10.5296/jbls.v3i1.2231.

Nawani, N., S.D. Nirpjit, and K. Jagdeep. 1998. A novel thermostable lipase from a thermophilic Bacillus sp. Characterization and esterification studies. Biotechnol. Lett. 20:997-1000. doi:10.1023/A:1005414428737.

Nithiyaa, P., M.Z. Nur Ain Izzati, K.Y. Umi, and B. Salleh. 2012. Diversity and morphological characteristics of Aspergillus species and Fusarium species isolated from cornmeal in Malaysia. Pertanika Journal of Tropical Agricultural Science 35:103-116. 
Peixoto-Nogueira, S.C., M. Michelin, J.H.A. Betini, J.A. Jorge. H.F. Terenzi, and M.L.T.M. Polizeli. 2009. Production of xylanase by Aspergilli using alternative carbon sources: application of the crude extract on cellulose pulp biobleaching. J. Ind. Microbiol. Biot. 36:149-155. doi:10.1007/s10295-008-0482-y.

Peberdy, J. F. 1990. Fungal cell walls. A review. In Biochemistry of Cell Walls and Membranes in Fungi. p. 5-30. P.J. Kuhn, A.P.J. Trinci, M.J. Jung, M.W. Goosey and L.G. Copping (eds.). Springer-Verlag, London, England

Qualhato, F.T., F.A.C. Lopes, A.S. Steindorff, R.S. Brandão, R.S.A. Jesuino, and C.J. Ulhoa. 2013. Mycoparasitism studies of Trichoderma species against three phytopathogenic fungi: evaluation of antagonism and hydrolytic enzyme production. Biotechnol. Lett. 35:1461-1468. doi:10.1007/s10529-013-1225-3.

Rawashdeh, R., I. Saadoun, and A. Mahasneh. 2005. Effect of cultural conditions on xylanase production by Streptomyces sp. (strain Ib 24D) and its potential to utilize tomato pomace. Afr. J. Biotechnol. 4:251-255.

Samson, R.A., and J. Varga. 2007. Aspergillus systematics in the genomic era. Studies in Mycology No. 59. CBS Fungal Biodiversity Center, Utrecht, The Netherlands.

Samson, R.A., C.M. Visagie, J. Houbraken, S.B. Hong, V. Hubka, C.H.W. Klaassen, et al. 2014. Phylopeny, identification and nomenclature of the genus Aspergillus. Studies in Mycology 78:141-173. doi:10.1016/j.simyco.2014.07.004.

Seidl, V., M. Marchetti, R. Schandl, G. Allmaier, and C.P. Kubicek. 2006. Epl1, the major secreted protein of Hypocrea atroviridis on glucose, is a member of a strongly conserved protein family comprising plant defense response elicitors. FEBS J. 273:4346-4359. doi:10.1111/j.1742-4658.2006.05435.x.

Silva, M.D., R.L. Batista, F.E. Rezende, P.M.H. Fungaro, D. Sartori, and E. Alves. 2011. Identification of fungi of the genus Aspergillus Section Nigri using polyphasic taxonomy. Braz. J. Microbiol. 42:761-773. doi:10.1590/ S1517-838220110002000044.

Sivan, A., and I. Chet. 1989. Degradation of fungal cell walls by lytic enzymes of Trichoderma harzianum. J. General Microbiol. 135:675-682. doi:10.1099/00221287-135-3-675.

Soares, C., T. Calado, and A. Venancio. 2013. Mycotoxin production by Aspergillus niger aggregate strains isolated from harvested maize in three Portuguese regions. Revista Iberoamericana de Micología 30:9-13. doi:10.1016/j.riam.2012.05.002.
Sugita, H., A. Kuruma, and Y. Deguchi. 1997. Purification and some properties of an $\alpha$-amylase from an anaerobic bacterium isolate from coastal sediment. Biosci. Biotechnol. Biochem. 10:1757-1759. doi:10.1271/bbb.61.1757.

Szekeres, A., B. Leitgeb, L. Kredics, L. Manczinger, and C. Vágvölgyi. 2006. A novel, image analysis based method for the evaluation of in vitro antagonism. J. Microbiol. Method 65:619-622. doi:10.1016/j.mimet.2005.09.014.

Tamura, K., G. Stecher, D. Peterson, A. Filipski, and S. Kumar. 2013. MEGA6: Molecular evolutionary genetics analysis version 6.0. Mol. Biol. Evol. 30:2725-2729. doi:10.1093/ molbev/mst197.

Thompson, G.R., and T.F. Patterson. 2008. Pulmonary aspergillosis. Semin. Respir. Crit. Care Med. 28:103-110. doi:10.1055/s-2008-1063849.

Tondje, P.R., D.P. Roberts, M.C. Bon, T. Widmer, G.J. Samuels, A. Ismaiel, et al. 2007. Isolation and identification of mycoparasitic isolates of Trichoderma asperellum with potential for suppression of black pod disease of cacao in Cameroon. Biol. Control 43:202-212. doi:10.1016/j.biocontrol.2007.08.004.

VanderMolen, K.M., H.A. Raja, T. El-Elimat, and N.H. Oberlies. 2013. Evaluation of culture media for the production of secondary metabolites in a natural products screening program. AMB Express. 3:71. doi:10.1186/2191-0855-3-71.

Vásquez V., .A.M. 2013. Producción de xilanasas por Aspergillus sp. en fermentación sumergida y fermentación en medio sólido. Tesis Maestría. Universidad Iberoamericana, Ciudad de México, México.

Vega, S.A., F.L. Valdés, and C.A. Rendón. 2012. Caracterización de una cepa nativa de Aspergillus niger y evaluación de la producción de ácido cítrico. Revista Universidad EAFIT 128:33-42.

Zhang, Y., M. Quiao, J. Xu, Y. Cao, Y., Zhang, K.-Q., and Yu, Z.-F. 2013. Genetic diversity and recombination in natural populations of the nematode-trapping fungus Arthrobotrys oligospora from China. Ecol. Evol. 3:312-325. doi.10.1002/ece3.450.

Zhang, Y.H., M.E. Himmel, and J.R. Mielenz. 2006. Outlook for cellulase improvement: Screening and selection strategies. Biotechnol. Adv. 24:452-481. doi:10.1016/j. biotechadv.2006.03.003. 